\title{
Metrics for Assessing Overall Performance of Inland Waterway Ports: A Bayesian Network Based Approach
}

\author{
Niamat Ullah Ibne Hossain, ${ }^{1}$ Farjana Nur, ${ }^{1}$ Raed Jaradat, ${ }^{1}$ Seyedmohsen Hosseini (D), \\ Mohammad Marufuzzaman, ${ }^{1}$ Stephen M. Puryear, ${ }^{3}$ and Randy K. Buchanan ${ }^{4}$ \\ ${ }^{1}$ Department of Industrial and Systems Engineering, Mississippi State University, P.O. Box 9542, Mississippi State, MS 39762, USA \\ ${ }^{2}$ Industrial Engineering Technology, University of Southern Mississippi, Long Beach, MS 39560, USA \\ ${ }^{3}$ Center for Advanced Vehicular Systems Extension (CAVSE), Mississippi State University, 153 Mississippi Parkway, \\ Canton, MS 39046, USA \\ ${ }^{4}$ Institute of Systems Engineering Research (ISER), U.S. Army Engineer Research Development Center (ERDC), \\ 3909 Halls Ferry Rd, Vicksburg, MS 39180, USA \\ Correspondence should be addressed to Seyedmohsen Hosseini; mohsen.hosseini@usm.edu
}

Received 4 December 2018; Accepted 31 March 2019; Published 2 May 2019

Academic Editor: Lucia Valentina Gambuzza

Copyright (C) 2019 Niamat Ullah Ibne Hossain et al. This is an open access article distributed under the Creative Commons Attribution License, which permits unrestricted use, distribution, and reproduction in any medium, provided the original work is properly cited.

\begin{abstract}
Because ports are considered to be the heart of the maritime transportation system, thereby assessing port performance is necessary for a nation's development and economic success. This study proposes a novel metric, namely, "port performance index (PPI)", to determine the overall performance and utilization of inland waterway ports based on six criteria, port facility, port availability, port economics, port service, port connectivity, and port environment. Unlike existing literature, which mainly ranks ports based on quantitative factors, this study utilizes a Bayesian Network (BN) model that focuses on both quantitative and qualitative factors to rank a port. The assessment of inland waterway port performance is further analyzed based on different advanced techniques such as sensitivity analysis and belief propagation. Insights drawn from the study show that all the six criteria are necessary to predict PPI. The study also showed that port service has the highest impact while port economics has the lowest impact among the six criteria on PPI for inland waterway ports.
\end{abstract}

\section{Introduction}

With the aid of technology, multiple transportation modes such as rail, water, road, and air are used to transfer goods from one destination to another in a timely fashion. Certain important goods, such as heavy load items or bulk cargos (e.g., ore, grains, and coal), machinery, bulk liquids and oils, automobiles, containers, and perishable refrigerated items require safe shipping to the desired destination. Research showed that ground or air transport is not recommended for these types of goods and the preferred transportation option is by maritime [1]. Maritime transportation is more economic, safe, and environmentally friendly.

Ports are mainstay on maritime transportation system as they play a major role in the global and domestic freight transportation. Ports are generally categorized into two major classes: seaports and inland waterway ports. Inland ports, known as coastal gateways for global trade, contribute to the rural, industrial, and agricultural development [2, 3]. Statistics show that 41 US states are being directly served by inland and intracoastal waterways for freight and passenger transportation. Inland waterway ports are located near a navigable river connected by a series of major canals and operated by lock and dam mechanism [4]. Unlike seaports, inland waterway ports do not have a deep draft; thus they cannot handle barges drafting more than 9 feet. Inland ports serve as a principal media for bulk transportation of the agriculture, mining, and manufacturing sectors with the connection of other intermodal facilities such as railroads and highways $[3,4]$. A high number of current US ports are still underperforming due to the lack of proper management plans and decisive operational strategies [5]. To improve the 
overall ports' performance, port authorities should advance their operational strategies by integrating cutting-edge technologies and agile planning. Port performance measurement is quite complex, due to the different port activities ranging from economic to technical to environmental. The overall ports' performance can be assessed through calculations of various performance activities $[6,7]$.

Due to the rapid advancement of global supply chain, inland waterway transport has become one of the important transportation modes (Weigmans et al., 2014). Thus, there is a need to employ a more "systemic" approach to better understand and manage any kind of undesirable consequences emanated from this complex system [8-10]. A major issue germane to inland port is the selection of ports based on performance indicators where these indicators determine the ranking of ports. Over the last decade, many portrelated researches including sea and inland waterway are conducted on performance management and site selection. For example, Wiegmans et al. (2014) conducted a detailed statistical analysis on the performance of the Dutch inland ports. They measured the performance of inland ports through transhipment level and growth in transhipment influenced by economic factors. Results indicated that the presence of a robust container terminal is necessary for a better port performance. Shetty and Dwarakish [7] identified a correlation between different port performance parameters such as loading/unloading rate, container dwell time, and terminal storage with overall productivity. The productivity is measured based on the number of vessels handled by the port. Along the same line, Kutin et al. [11] analyzed the relative efficiencies of fifty ASEAN ports and rank the ports efficiencies based on inland or sea type and supportive yard equipment. Alamoush [12] used a quantitative approach to study the impact of hinterland transport, specifically land transport (trucks) on the operational performance of the Jordanian inland port system. The findings from this study indicate that efficient hinterland transport system improves the operational performance of the inland waterway port. Oliveira and Cariou [13] developed a truncated regression model to explore the influence of interport competition on port efficacy and to investigate how the interrelationship between interport competition and efficacy can be varied if the assessment is performed at different geographic level. They suggested that interport competition has a reverse relationship with port efficacy and this negative relationship becomes more widespread when the competition occurs at a regional level compared to global levels. Bichou and Gray [14] proposed a conceptual framework of port performance through the lens of logistic and supply chain perspectives.

The current body of the literature is replete with other theoretical and empirical studies that focus on the subject of port performance and different types of port efficiencies. Interested readers can refer to the works of Coto-Millan et al. [15], Notteboom et al. [16], Barros [17], Díaz-Hernández et al. [18], Panayides et al. [19], Wanke [20], Chang and Tovar $[21,22]$, and Tovar and Wall [23]. Likewise, there are some analytical studies that have been devoted to other aspects pertaining to seaports, such as seaport characterization and classification (e.g., [24]), port operations and resilience (e.g.,
[25-27]), port selection (e.g., [28-31]), and port competitiveness (e.g., $[32,33])$. In this research we propose a unique set of determinants (i) port facility, (ii) port availability, (iii) port economics (iv) port service, (v) port connectivity, and (vi) port environment that impact the inland port performance. These determinants were derived based on Minimum Link Set (MLS) perspective. A MLS is a minimum set of operational factor or component required for the system to actively perform (Johansen and Tien; 2017), which implies failure of any factor or component within a system triggers cascading impact and leads to failure of the MLS (Jianag et al., 2016). Table 1 provides a summary of the current themes related to the different aspects of port literature. These themes serve as a baseline in the development of the proposed model.

Although there are many theoretical and empirical studies focused on the analysis and characterization of seaports, there is scant research that has attempted to quantify the performance of inland port using unique set of determinants. To address this gap, the following are the contributions made by this research:

(i) Propose a new metric "port performance indicator (PPI)" to assess the probability of an inland port performance.

(ii) Propose a probabilistic graphical model, a Bayesian network (BN), to predict the probability of port performance based on six criteria.

(iii) Conduct different types of analysis such as belief propagation and sensitivity analyses to provide better insights regarding the results of the proposed model.

(iv) Use $\mathrm{BN}$ as an effective tool in solving transportation and logistics management problems.

To the best of our knowledge, this is the first attempt to assess the probability of inland port performance using a Bayesian approach (BN). This research also presents the efficacy of $\mathrm{BN}$ tool in the context of transportation and logistics management. BN has some advantages over other approaches. $\mathrm{BN}$ is a powerful analytical tool that can be used for decision-making under uncertainty. Another important feature of $\mathrm{BN}$ is the ability to model both qualitative and quantitative variables which is different from other approaches such as swing weight, Analytical Hierarchy Process (AHP), or Technique for Order of Preference by Similarity to Ideal Solution (TOPSIS). BN can also be used to conduct probabilistic scenario analysis known as belief propagation analysis. $\mathrm{BN}$ accounts for all causal factors to produce a final model, to reduce the burden of parameter acquisition, and to overturn the previous assumption by taking new evidences into consideration such as subjective belief and objective data [34]. The Bayesian approach has been used in different domains and applications such as electrical infrastructure system [35], security management [36], customer service management [37], traffic accidents [38], manufacturing systems [39], natural resource management [40,41], power system [42], and data classification [43], electric vehicle [44], and supply chain and logistics $[45,46]$.

An overview of $\mathrm{BN}$ is presented below, followed by the identification of the criteria and subcriteria that impact the 
TABLE 1: Current themes of the port literature.

\begin{tabular}{|c|c|c|}
\hline Authors & Measures for port & Approach \\
\hline Wiegmans et al. (2015) & Inland port performance & Statistical (regression) analysis \\
\hline Shetty and Dwarakish [7] & Inland port performance and productivity & Statistical analysis \\
\hline Kutin et al. [11] & Relative efficiencies & Data Envelopment Analysis (DEA) \\
\hline Alamoush [12] & Port operational performance & Conceptual framework with analytical model \\
\hline Oliveira and Cariou [13] & Port efficiency & Data Envelopment Analysis (DEA) \\
\hline Bichou and Gray [14] & Port performance & Conceptual logistic and supply chain approach \\
\hline Coto-Millan et al. [15] & Port economic efficiency & Stochastic Cost Frontier (SCF) \\
\hline Notteboom et al. [16] & Relative efficiency of container terminal & Stochastic Cost Frontier (SCF) \\
\hline Baros [17] & Technical efficiency & Stochastic Cost Frontier (SCF) \\
\hline Díaz-Hernández et al. [18] & Technical and allocative efficiency & Stochastic Cost Frontier (SCF) \\
\hline Panayides et al. [19] & Economic efficiency & Data Envelopment Analysis (DEA) \\
\hline Wanke [20] & $\begin{array}{l}\text { Physical infrastructure efficiency, shipment } \\
\text { consolidation efficiency }\end{array}$ & Data Envelopment Analysis (DEA) \\
\hline Chang and Tovar $[21,22]$ & Technical efficiency & Stochastic Distance Function (SDF) \\
\hline Tovar and Wall [23] & Port productive efficiency & Directional technology distance function approach \\
\hline Bichou and Gray [24] & Terminology for classifying seaport & Conceptual framework \\
\hline Hosseini and Barker $[25,26]$ & Resilience & Bayesian approach \\
\hline Sierra et al. [27] & Harbour operability & Numerical Model \\
\hline Ugboma et al. [28] & Port selection & Analytical Hierarchy Process (AHP) \\
\hline Chang et al. [29] & Port selection factor & Exploratory factor and confirmatory factor analyses \\
\hline Gohomene (2008) & Port selection & Analytical Hierarchy Process (AHP) \\
\hline Nur et al. [31] & Port selection & Stochastic Analytical Hierarchy Process (SAHP) \\
\hline Song and Yeo [32] & Competitiveness of container ports & Analytical Hierarchy Process (AHP) \\
\hline Yeo et al. [33] & Competitiveness of container ports & Fuzzy methodology \\
\hline
\end{tabular}

overall inland port performance and translate these criteria into BN model to assess the probability of PPI. From this, belief propagation and sensitivity analyses are presented, respectively. The paper concludes with implications, recommendations, and future research.

\section{Fundamentals of Bayesian Network}

$\mathrm{BN}$ is a Directed Acyclic Graph (DAG) which consists of vertices (nodes) and edges (arcs) where vertices represent the variables and edges signify the relationship between the two variables in the existing network. BNs are structured based on Bayes' theorem, capable of making statistical inferences in a rational way by updating the prior beliefs of any event which means entering an evidence in an child node will lead to backward belief propagation and ultimately result in updating the probability distributions for the parent node(s) and vice versa [34]. BN requires fewer probability parameters compared to a full joint probability model. Equation (1) represents the generic rule of the Bayesian theorem [47].

$$
P_{R}\left(A_{1}, A_{2}, A_{3} \ldots A_{n}\right)=\prod_{i=1}^{n} P_{R}\left(a_{i} \mid \mu_{i}\right)=\prod_{i=1}^{n} \phi_{A_{i} \mid \mu_{i}}
$$

In (1), the underlying network is specified by a pair $\mathrm{R}=\{G, \Theta\}$ where $G$ is the directed acyclic consisting of a set of random variables $A_{1}, A_{2}, A_{3} \ldots A_{n}$, and $\Theta$ representing the set of the probability functions. Each $a_{i}$ in $A_{i}$ is provisioned on $\mu_{\mathrm{i}}$ for the set of the parameters of $A_{i}$ in $G$.

In the underlying structure of a $\mathrm{BN}$, the initial probabilities (unconditional) or prior information of the root nodes can be obtained from a subjective judgment (e.g., expert knowledge /historical data) or through a frequentist approach (observed data). The conditional probabilities refer to the quantitative degree of belief to describe uncertainty among nodes. In some cases, it is challenging to define the conditional probability table (CPT) for a large set of data. Thus, we used AgenaRisk software to offset this challenge, having said that Bayesian equation is used to calculate CPT with known initial probabilities of each node as shown in (2) [48].

$$
P\left(A_{j} \mid B\right)=\frac{P\left(B \mid A_{j}\right) \times P\left(A_{j}\right)}{P\left(B \mid A_{i}\right) \times P\left(A_{i}\right)}
$$

where $i=1,2, \ldots, n ; j=1,2$.

To illustrate the operational principle of $\mathrm{BN}$ networks, let us consider a $\mathrm{BN}$ structure with a set of variables $R=\left\{A_{1}, A_{2}, A_{3}, A_{4}, A_{5}, A_{6}\right\}$ and a set of edges to show the conditional interdependencies among the variables (see 


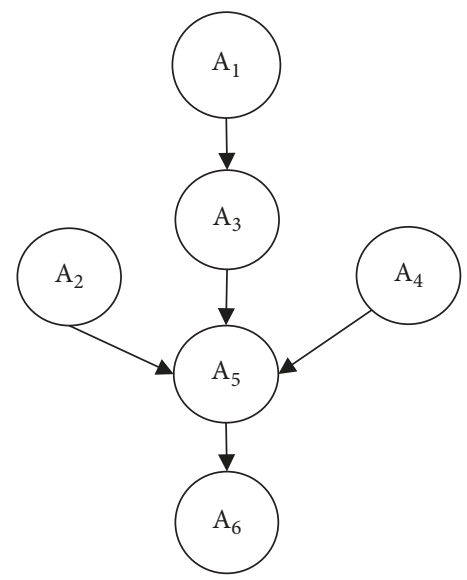

Figure 1: A sample of the Bayesian Network (BN) with six nodes.

Phase-I

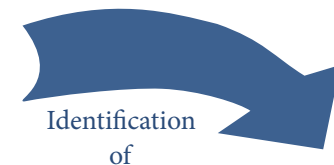

of

Phase-II

Factors \& Sub Factors

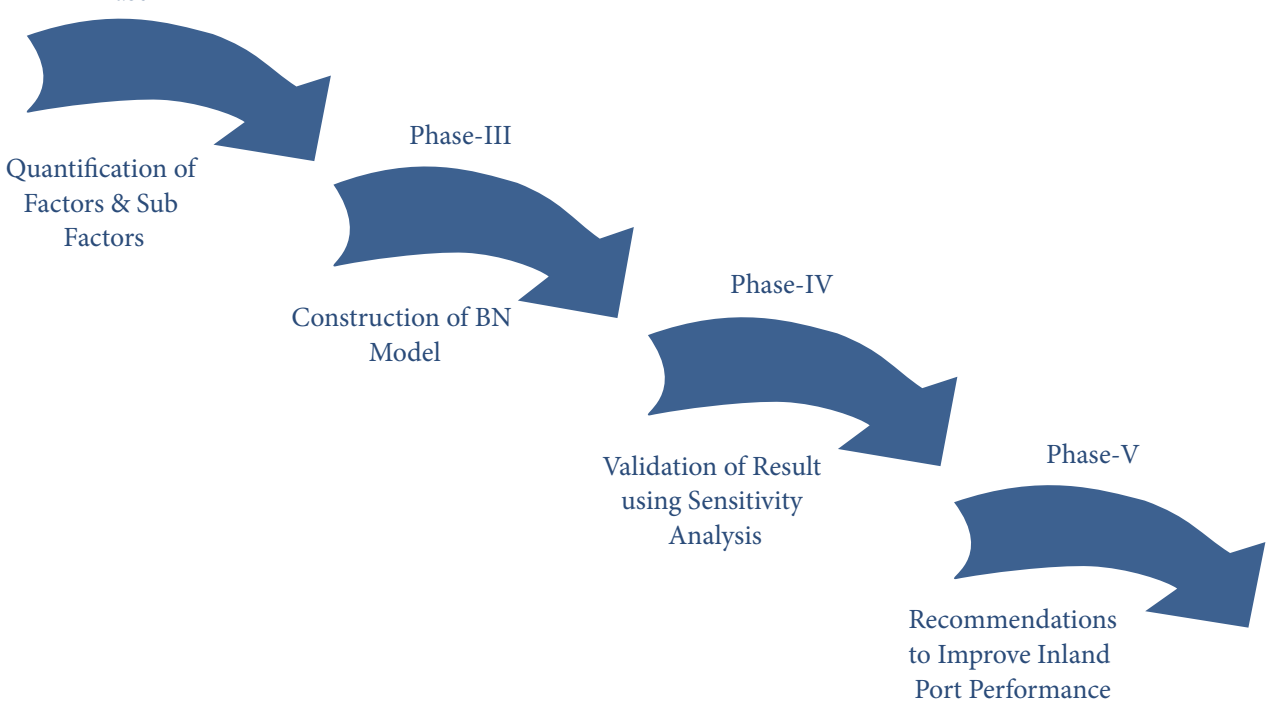

FIGURE 2: Proposed framework for inland port performance assessment.

Figure 1). The general expression of the full joint probability distribution can be represented as follows:

$$
\begin{aligned}
P & \left(A_{1}, A_{2}, A_{3}, \ldots A_{n}\right)=P\left(A_{1} \mid A_{2}, A_{3}, \ldots A_{n}\right) \\
& \cdot P\left(A_{2} \mid A_{3}, \ldots, A_{n}\right) \ldots P\left(A_{n-1} \mid A_{n}\right) P\left(A_{n}\right) \\
& =\prod_{i=1}^{n} P\left(A_{i} \mid \operatorname{Parents}\left(A_{i}\right)\right)
\end{aligned}
$$

The corresponding decomposition of the joint distribution of variables can be streamlined as follows:

$$
\begin{aligned}
& P\left(A_{1}, A_{2}, A_{3} \ldots A_{6}\right)=P\left(A_{1}\right) P\left(A_{2}\right) P\left(A_{4}\right) \\
& \quad \cdot P\left(A_{3} \mid A_{1}\right) P\left(A_{5} \mid A_{2}, A_{3}, A_{4}\right) P\left(A_{6} \mid A_{5}\right) A_{4}
\end{aligned}
$$

\section{Proposed Framework for Inland Port Performance Assessment}

The proposed framework consists of five phases as illustrated in Figure 2.

(i) Phase I. Identification of factors and subfactors: the first phase is to identify the factors and subfactors that could impact the performance of port infrastructure. First, the current research related to port performance is studied and analyzed, and initial subcriteria are constructed. Second, opinions from domain experts are incorporated into the scope of port performance management and the less important subcriteria are discarded, and finally all the subfactors are clustered 
TABLE 2: Inland port performance index scale.

\begin{tabular}{lcc}
\hline Intensity of PPI & Definition & Significance \\
\hline PPI $>80 \%$ & High Standard & Maintains superior standard on all the performance criteria. \\
\hline $60 \%<$ PPI $<80 \%$ & Moderate Standard & Meets adequate performance standard, but the scope of improvement is available. \\
\hline PPI $<60 \%$ & Low Standard & Performance level is lower than average and significant improvement is needed. \\
\hline
\end{tabular}

into six main criteria, namely, (i) port facility, (ii) port availability, (iii) port economics, (iv) port service, ( $v$ ) port connectivity, and (vi) port environment.

(ii) Phase II. Quantification and assessment of factors and subfactors: the second phase is to quantify the factors and subfactors. It also includes the determination of the likelihood of the related factors based on the subjective or frequentist approach.

(iii) Phase III. Construction of $\mathrm{BN}$ model: a $\mathrm{BN}$ is used to quantify the probability of the port performance.

(iv) Phase IV. Analysis of result: different techniques such as sensitivity analysis and belief propagation analysis were conducted to draw the insights from Phase III.

(v) Phase V. Recommendation for port performance improvement: based on the analysis, different recommendations are provided to improve the overall port performance.

\subsection{Performance Standard for Inland Waterway Port}

3.1.1. Proposed Inland Port Performance Index (PPI). Based on existing literature, a number of interrelated factors that influence the performance of inland waterway ports are identified. This research summarized all the possible factors and classified them into six criteria: (i) port facility, (ii) port availability, (iii) port economics, (iv) port service, (v) port connectivity, and (vi) port environment. The proposed Inland Port Performance Index (PPI) describes the probability of the performance standard that an inland waterway port can meet. For instance, the probability of PPI being $80 \%$ true means that there is $80 \%$ likelihood that the specific port will meet the performance standard based on the cited criteria.

The characterization of PPI incorporates the most significant parameters that impact the performance standard of the inland waterway port. In order to express PPI through a numerical scale, a value between 0 and 100 is assigned. It is important to note that the selected metric is based on expert knowledge within inland waterway port system and is used to highlight the overall performance of an inland waterway port. The subjective description of the metric values of PPI is explained in Table 2 and the base model of the $\mathrm{BN}$ for measuring PPI is illustrated in Figure 3.

3.1.2. Port Facility (Criterion \#1). An inland port is highly integrated with a maritime terminal to ensure smooth flow of logistical activities across the globe. Port terminal amenities and other key facilities such as warehouse area, outdoor ground storage, and dock-wall depth govern the overall facility of the inland port for freight handling and distribution. (i) Terminal facility: it consists of three contributors port throughput, types of existing terminal, and number of diversified products.

(a) Throughput: it is volume of cargo or number of vessels that a port can handle over time. Throughput can be measured in terms of tons or transportation equivalent units (TEU). Different factors such as competition between ports, international and domestic cargo demand, and business arrangements can influence the terminal throughput [49].

(b) Types of existing terminal: from a transport facility viewpoint, a top-tier inland port possesses three kinds of terminals: Satellite terminal located near the port facility and used mainly for container trans-loading, Freight distribution cluster or load center dedicated to support warehousing and logistic functions, and intermodal terminal used to regulate freight circulation through intermodal facilities [50].

(c) Number of diversified products: based on United Nations Conference on Trade and Development (UNCTAD), five categories of seaborne trade that a port can handle are containers, petroleum, crude oil, main bulk commodities, and other dry products. However, for an inland port, diversity in the type of products handled is limited to two to three types.

(ii) Key facilities: warehouse area, outdoor ground storage, and dock-wall depth play a vital role in freight storage and port performance.

(a) Warehouse area: warehouse facility is tied up with freight storage and distribution operations. Sometimes warehouse areas are facilitated by staging areas to support loading and unloading operations.

(b) Outdoor ground storage: outdoor ground storage offers port expansion opportunity due to possible growth rate in port throughput. Some ports use outdoor ground storage as cargo staging/assembly zone, maintenance area, barge consolidation and deconsolidation facility, and container depot.

(c) Dock-wall: dock wall facilitates berthing area for vessel/cargo.

3.1.3. Modelling of Port Facility. In order to model port facility, three variables were used: (i) Boolean variables are 


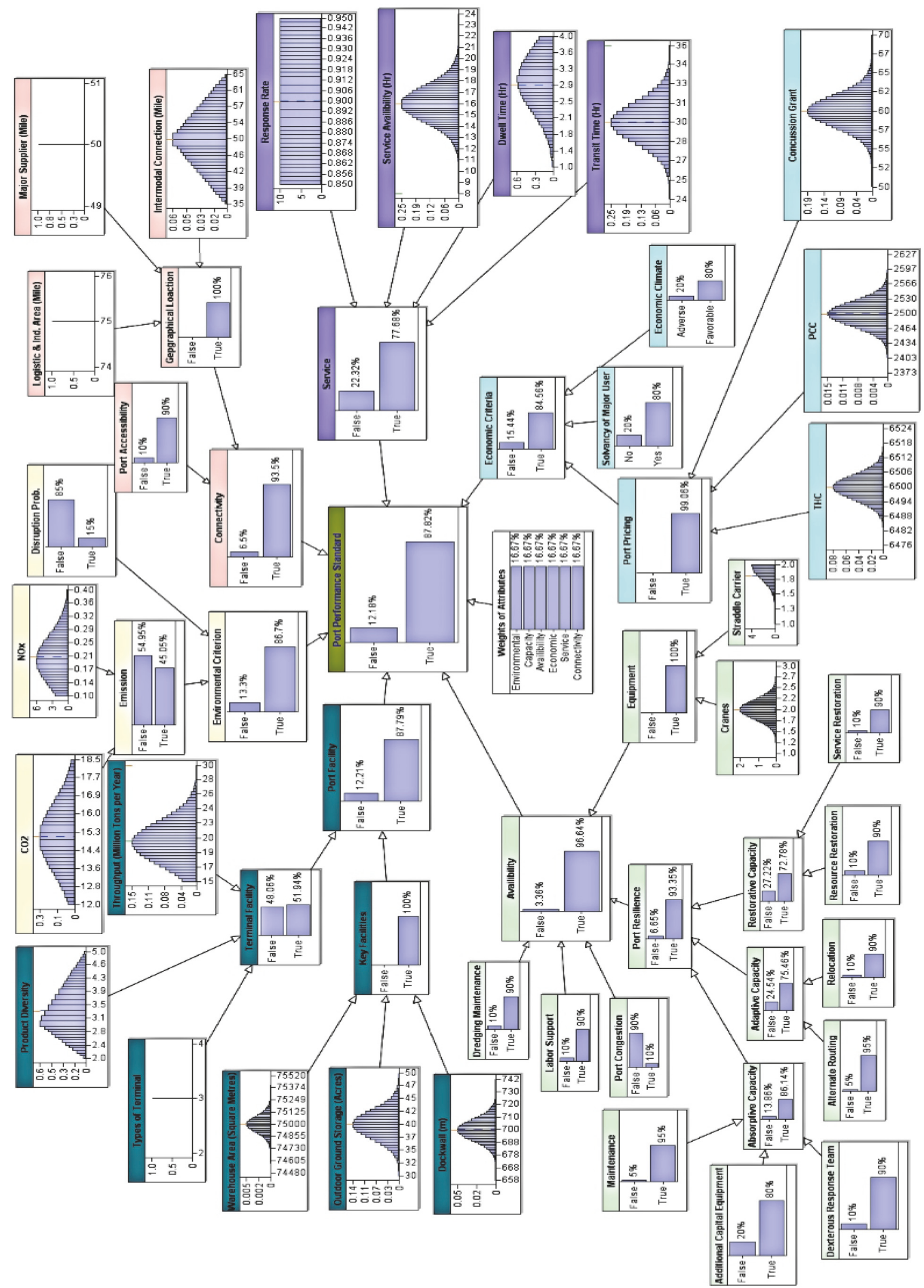

FIgURE 3: Base model of the Bayesian Network for measuring PPI of inland port. 
expressed in forms of a dichotomous response (true/false, yes/no) to present positive and negative outcomes respectively, (ii) fixed variables are modelled in constant values, and (iii) continuous variables are random variables with a known probability distribution.

A Boolean variable with two states of true and false are used to model facility, terminal facility, and key facilities nodes. The true state represents a positive outcome while the false state indicates a negative outcome. For instance, in Figure 3 the probability of facility being true or likelihood of meeting port facility is $87.41 \%$ while the probability of facility being false is $12.58 \%$. Similar logic is also applicable to the other two Boolean nodes (terminal facility and key facilities).

Truncated normal distribution is used to model continuous variables such as throughput, warehouse facility, outdoor ground storage, and dock-wall area. Truncated normal distribution is a simple modification of a normal distribution that confines the mean values between lower and upper bounds. For example, the area of the warehouse facility cannot be negative and maximum warehouse area for the inland port does not generally exceed $1,50000 \mathrm{~m}^{2}$. Hence, the truncated normal distribution is found to be the most appropriate distribution to model the aforementioned continuous variables. The truncated distribution is defined in terms of four parameters: $\mu$, mean (i.e., central tendency); $\sigma^{2}$, variance (i.e., confidence in the results); lower bound and upper bound.

It is apparent from Figure 3 that port facility is conditioned upon terminal facility and key facilities. There might be other hidden factors contributing to port facility. This can be better described by the NoisyOR function. These hidden or missing parameters are known as "leak parameters" in NoisyOR function (see (5)).

$$
\text { NoisyOR }\left(A_{1}, S_{1}, A_{2}, S_{2}, \ldots A_{n}, S_{n}, l\right)
$$

Leak factor (l) can be defined as the extent to which missing factors from the model can contribute to the consequence being true. It is the probability that $B$ will be true when all of its causal factors are false. The conditional probability of $B$ obtained with the NoisyOR function is presented below in (6).

$$
\begin{aligned}
& P\left(B=\text { True } \mid A_{1}, A_{2} \ldots A_{n}\right) \\
& =1 \\
& \quad-\prod_{i=1}^{n}\left[\left(1-P\left(B=\text { True } \mid A_{i}=\text { True }\right)(1-P(l))\right\}\right]
\end{aligned}
$$

The modelling procedure for port facility and its contributors are summarized in Table 3 .

In the proposed $\mathrm{BN}$ model, in order to calculate the posterior probability of the "port facility", we used NoisyOR function, which is represented in (7). The equation means that, in order to meet port facility, both factor terminal facility and key facility are equally responsible (75\%) and other hidden factors are contributing rest of $25 \%$ to achieve desired port facility.

$$
\text { Port Capacity }=\text { NoisyOR (Terminal Facility, 0.75, }
$$

Key Facility, 0.75, 0.25)

3.1.4. Port Availability (Criterion \#2). Availability is the level to which the system (port) can self-organize itself to avoid any discontinuity of the system's performance due to undesirable consequences. In terms of inland port, availability refers to the readiness of the adequate resources to perform the daily operation. Inland port availabilities can be measured through port resilience, the readiness of different kinds of equipment and labour support, dredging maintenance, and congestion rate.

(i) Port Equipment. In order to perform daily operations such as handling cargo and stevedore operations, port authorities use different kinds of capital equipment, such as gang-tree/rubber-tree cranes, mooring instruments, forklifts, reach stackers, and towing vehicles. For the inland waterway port, gang-tree cranes and straddle carriers are most commonly used.

(ii) Port Resilience. Ability of a port to bounce back to its normal operating condition after any type of disruption such as adverse weather conditions, humanmade error, and/or cyberattack. Resilience capacities are the strategies to recover a region/entity from any shock or external perturbation due to disruption. Resilience capacities can expressed by means of absorptive capacity, adaptive capacity, and restorative capacity of the corresponding system [35, 39, 51-53]. It is generally designed based on metastructure under internal deterioration and external perturbation [54].

Absorptive capacity is an endogenous feature of the system and is also considered to be the first course of defense to minimize the impacts of the disruption $[25,26,39,52]$. Maintenance, availability of additional capital equipment, and skillful response team are the mainstay of the port absorptive capacity. Adaptive capacity, which is considered to be the midline of defense, is described as the ability of a system to selforganize itself and provide immediate solutions to cope with the external shock without any recovery activity $[25,26,35]$. Alternate routing and relocating of resources are the key factors germane to the adaptive capacity within port infrastructure. Restorative capacity considered to be the last line of defense is the degree to which a system can efficiently repair or restore from the degraded state [35]. Within the restorative capacity of port infrastructure, two salient determinants are identified: restoration of resources and restoration of service.

(iii) Workforce. Workforce is an asset to any port infrastructure. Operators and stevedores also ensure proper utilization of the available resources and reduce the delay during port operations such as loading and 
TABLE 3: Modelling of variables contributed to port facility.

\begin{tabular}{|c|c|c|}
\hline Variable Name & $\begin{array}{l}\text { Modelling } \\
\text { Technique }\end{array}$ & Modelling Description \\
\hline Throughput & TNORM & $\begin{array}{l}\text { Based on inland port statistics, a truncated normal distribution is used to approximate the } \\
\text { annual throughput of an inland port with an average of } 20 \text { million ton/year. }\end{array}$ \\
\hline Product Diversity & Trinagular & $\begin{array}{l}\text { Product diversity is approximated with a triangular distribution with minimum, most likely, } \\
\text { and maximum of } 2,3 \text {, and } 5 \text { respectively. }\end{array}$ \\
\hline Types of Terminal & Arithmetic & Types of the terminal are fixed and equal to 3 to avail the proper terminal facility. \\
\hline Warehouse Area & TNORM & Warehouse area is defined by truncated normal distribution with a mean of $7,5000 \mathrm{~m}^{2}$. \\
\hline Outdoor Ground Storage & TNORM & $\begin{array}{l}\text { The outdoor storage area is approximated using truncated normal distribution with an } \\
\text { average of } 40 \text { acres. }\end{array}$ \\
\hline Dock-wall & TNORM & $\begin{array}{l}\text { A truncated normal distribution is used to approximate the dock wall parameter of an } \\
\text { inland port with an average of } 700 \mathrm{~m} .\end{array}$ \\
\hline Terminal Facility & $\begin{array}{l}\text { Comparative } \\
\text { Expression }\end{array}$ & $\begin{array}{l}\text { Threshold for throughput and product diversity are set as } 20 \text { million/year and } 2 \text { respectively } \\
\text { while port should have exactly } 3 \text { types of terminal to avail the proper terminal facility. }\end{array}$ \\
\hline Key Facilities & $\begin{array}{l}\text { Comparative } \\
\text { Expression }\end{array}$ & $\begin{array}{l}\text { The key facilities will be suitable (true) for port operational activities if the parameters of } \\
\text { dock-wall, warehouse area and outdoor ground Storage are higher than } 600 \mathrm{~m}, 50,000 \mathrm{~m}^{2} \\
\text { and } 30 \text { acres respectively. }\end{array}$ \\
\hline
\end{tabular}

TABLE 4: Modelling of equipment variable.

\begin{tabular}{lcc}
\hline Variable Name & $\begin{array}{c}\text { Modelling } \\
\text { Technique }\end{array}$ & Modelling Description \\
\hline Equipment & $\begin{array}{c}\text { Comparative } \\
\text { Expression }\end{array}$ & $\begin{array}{c}\text { An IF logic is used for modelling an "equipment" node. The threshold for number of } \\
\text { cranes and straddle is considered to be one In order to perform the regular operation, the } \\
\text { port equipment requirements will be met (true state) if the number of cranes and straddle } \\
\text { is more than one and otherwise not (false state). }\end{array}$ \\
\hline
\end{tabular}

unloading, recouping, grading, fuel transfer from vessel to the pier, gate operations, and others.

(iv) Port Congestion. A main parameter to measure port availability. Congestion occurs when vessels enter into a queue and wait for an extended period of time to access port facilities.

(v) Dredging Maintenance. Dredging is important for inland ports to maintain the desired water depth at their approach channels, specifically for those ports where the waterway accumulates silt quickly. Enhanced dredging capability also positively impacts the availability of the port.

3.1.5. Modelling of Port Availability. Boolean variables were used to model the contributors of port availability. For instance, the prior distribution of the resilience variable with two states of True $=93.35 \%$ and False $=6.65 \%$, which means that there is an $93.35 \%$ chance that a strong resilient port infrastructure would contribute to increase the availability of the port facility, while there is a $6.65 \%$ chance that it may fail. In other words, the resilience of the port system is successful 93.35\% (True state) and fails $6.65 \%$ (False state) of the time. The same logic is applicable for other Boolean nodes under port availability variables. Table 4 provides detailed model description of the equipment variables.
Port resilience and availability criterion is designed using NoisyOR function and equation is presented below:

Port resilience $=$ NoisyOR (absorptiev capacity,

0.70 , adaptive capacity, 0.70 , restorative caapcity,

$0.80,0.15)$

Port Availabilily

= NoisyOR (Dredging maintenance, 0.50,

labor support, 0.50 , port congestion, 0.20 ,

port reslience, 0.50 , equipment, $0.50,0.15$ )

3.1.6. Port Economics (Criterion \#3). Port economics: the solvency of the major stakeholders, the overall status of the global economy, and port pricing also influence the port economics.

Port associated cost consists of terminal-handling costs, port calling cost, and concession pricing.

(i) Terminal-handling cost (THC): it is related to the cost for loading or unloading, container service and clearance, storage, repacking, and forwarding. It includes all services essential for moving the freight 
TABLE 5: Modelling of variables contributed to port pricing.

\begin{tabular}{lcc}
\hline Variable Name & $\begin{array}{l}\text { Modelling } \\
\text { Technique }\end{array}$ & Description \\
\hline $\begin{array}{l}\text { Terminal Handling Cost } \\
(\text { THC) }\end{array}$ & TNORM & $\begin{array}{c}\text { Based on inland waterway port data, the average terminal cost is the } \$ 6,500 / \text { barge with a } \\
\text { variance of } \$ 25 \text { and cost varies from The } \$ 5,000 \text { to } \$ 8,000 \text { based on the size of the barge } \\
\text { and other related factors. }\end{array}$ \\
\hline $\begin{array}{l}\text { Port Calling Cost (PCC) } \\
\begin{array}{l}\text { Concession pricing } \\
\text { (Upfront fee) }\end{array}\end{array}$ & TNORM & $\begin{array}{c}\text { Port calling cost varies from } \$ 1,800 \text { to } \$ 3,800 \text { depending upon the size of the vessel with } \\
\text { an average of } \$ 2,500 \text { dollar/ vessel. }\end{array}$ \\
\hline
\end{tabular}

TABLE 6: Modelling of port pricing variable.

\begin{tabular}{lcc}
\hline Variable Name & Modelling Technique & Description \\
\hline Port pricing cost & Comparative Expression & $\begin{array}{c}\text { IF the THC, PCC and concussion grant are lower than } \$ 7000, \$ 2,800 \text { and } \$ 65 \text { million, } \\
\text { respectively then the port economy cost is within limit (true state), otherwise not (false } \\
\text { state). }\end{array}$ \\
\hline
\end{tabular}

onwards through the port before being loaded onto a vessel. More precisely, beyond the sea freight, THC is the charge that is paid by shippers for handling the containers at the inland port.

(ii) Port calling cost: it is the costs related to all types of services offered to handle a ship or vessel. More precisely, it is the summation of prices to be paid for various services including access to the terminal, pilotage, time costs, damage and delay, and bunkering.

(iii) Concession cost: it is decided by the port governing body and it is the cost of acquiring a dedicated maritime facility such as a terminal, yard, or outdoor storage. It is mainly a leasehold agreement and used for a variety of reasons.

Tables 6 and 5 describe the modelling details of port pricing variables and its contributed factors, respectively.

NoisyOR function, which is discussed in the previous section, is applied to design the economic criterion as presented below.

$$
\begin{aligned}
& \text { Port Ecomonics }=\text { NoisyOR }(\text { Port pricing, } 0.50, \\
& \text { solvency of major user, } 0.50, \text { economic climate, }
\end{aligned}
$$

3.1.7. Port Service (Criterion \#4). An inland port's service level indicator is highly integrated with response rate, service availability, container dwell time, and vessel transit time at the port.

(i) Response rate: a measure of port service including faster documentation, availability and quick updates of electronic information, early detection, and response to problems. The higher response rate reduces unnecessary cost pertaining to any port.

(ii) Service availability: it is a measure of port performance that refers to port services at any time of the day or the service is restricted for a fixed time. High service availability means the operational hours of a port is higher than normal and vice versa. Generally, for an inland waterway port the service hours vary from 8 to 24 hours per day.

(iii) Dwell time: dwell time is measured by the amount of time a container waits to be picked up at a marine terminal after being offloaded from a ship or vessel [55]. This is considered as a key benchmark for port's service level indicator. Port authority always experiences a constant challenge to keep the dwell time down while accommodating inbound and outbound vessels.

(iv) Transit time: transit time management is one of the main concerns of port authority. It is the amount of time that a vessel spends in different ports on the way to its destination port. This also includes waiting time dockside before loading/unloading.

3.1.8. Modelling of Port Service. As apparent from Figure 3, port service consists of four main contributors including response rate, service availability, dwell time, and transit time. Truncated normal distribution similar to what is explained in the previous section is applied to model the aforementioned four contributors. The modelling procedure of port service and its contributors are summarized in Tables 7 and 8 . The modeling procedure of geographical location and port accessibility is summerized in Table 9.

3.1.9. Port Connectivity (Criterion \#5). Connectivity refers to the level of ease that an inland port supports freight transportation through the supply chain network.

(i) Geographical Location. Some geographic areas possess natural advantages for business flourishment. It is beneficial for an inland waterway port to have a logistic cluster, a major supplier, and an intermodal connection within its vicinity. Geographical locations 
TABLE 7: NPTs of the variables describing response rate, service availability, dwell time, and transit time.

\begin{tabular}{|c|c|c|}
\hline Variable Name & Modelling Technique & Modelling Description \\
\hline Response rate & TNORM & $\begin{array}{l}\text { Based on the inland port statistics, the response rate of inland port varies from } 85 \% \text { to } \\
\qquad 95 \% \text { with an average of } 90 \% .\end{array}$ \\
\hline Service availability & TNORM & $\begin{array}{l}\text { At the worst possible scenario, the port operating hours are not lower than } 16 \text { hours and } \\
\text { at the best possible the port provides } 24 \text { hours service a day. }\end{array}$ \\
\hline Dwell time & TNORM & $\begin{array}{l}\text { Dwell time is modelled with a truncated normal distribution with mean, LB, and UB of } 3 \text {, } \\
\qquad 1 \text {, and } 4 \text { hours respectively. }\end{array}$ \\
\hline Transit time & TNORM & $\begin{array}{l}\text { A truncated normal distribution is used to approximate the transit time of a vessel with } \\
\text { an average of } 24 \mathrm{hr} \text {. }\end{array}$ \\
\hline
\end{tabular}

TABLE 8: Modelling of service variable.

\begin{tabular}{lcr}
\hline Variable Name & Modelling Technique & Modelling Description \\
\hline Port Service & Comparative Expression & $\begin{array}{r}\text { If the values of response rate or service availability are greater than 90\% or 12 hours, } \\
\text { respectively AND dwell time or transit time is lower than 3 or 30 hours, respectively then } \\
\text { the satisfactory service level is achieved (true state), otherwise not (false state) }\end{array}$ \\
\hline
\end{tabular}

TABLE 9: NPTs of the variables describing the contributor to geographical location and port accessibility.

\begin{tabular}{|c|c|c|}
\hline Variable Name & $\begin{array}{l}\text { Modelling } \\
\text { Technique }\end{array}$ & Modelling Description \\
\hline $\begin{array}{l}\text { Distance to Logistic \& } \\
\text { Industrial Area }\end{array}$ & Arithmetic & Distance to logistic \& industrial cluster is constant: 75 miles. \\
\hline Distance to Major Supplier & Arithmetic & The distance between port and major supplier is constant: 50 miles. \\
\hline $\begin{array}{l}\text { Distance to Intermodal } \\
\text { Connection }\end{array}$ & Triangular & $\begin{array}{l}\text { The distance between the port and the intermodal connection is modelled with triangular } \\
\text { distribution with mean, LB, and UB of } 50,35 \text { and } 65 \text { miles respectively. }\end{array}$ \\
\hline Geographical Location & $\begin{array}{l}\text { Comparative } \\
\text { Expression }\end{array}$ & $\begin{array}{l}\text { Based on the historical data, if the logistics cluster, major supplier, and intermodal } \\
\text { connection are within } 75,50 \text {, and } 50 \text { miles from the inland port location, then port has } \\
\text { suitable geographical location for trade and commence (true state), otherwise not (false). }\end{array}$ \\
\hline Port accessibilities & Boolean & $\begin{array}{c}\text { We assume that } 90 \% \text { of the time, the port is accessible by all required modes of } \\
\text { transportation. On very few occasions, port entire accessibility is halted by natural } \\
\text { calamities, human error and/or cyber-attack. }\end{array}$ \\
\hline
\end{tabular}

associated with modal accessibility and availability of inland regional access influence shaping of the development of surrounding locality [56]. All these criteria boost productivity, save time, lower the logistic cost, and provide access to global markets.

(a) Proximity to the industrial area and logistics cluster: logistics clusters provide integrated services in logistics. If the port location is close to the logistics cluster center, the port may perform better than port locations farther away from the cluster center. Port proximity to industrial areas has a great impact on port choice.

(b) Proximity to major supplier: proximity to major suppliers will enhance national and international trade throughout the port. Traders can exploit economies of scale in shipping products and, in turn, will be benefitted from in time delivery and lower inventory holding costs.

(c) Proximity to intermodal connection: the strength of inland intermodal transportation network includes the availability of railway, roadway, and rail spur in the port province. The ports that are close to intermodal connection generally get better transportation facilities, such as highways, railroads, and airports.

(ii) Port Accessibility. Port accessibility means the port location can be approachable by different modes of transportation. Port accessibility depends upon the location and the overall infrastructure of the port.

3.1.10. Modelling of Port Connectivity. NoisyOR function, as discussed in the previous section, is used here to calculate the conditional probability of connectivity criterion as defined in

$$
\begin{gathered}
\text { Port Connectivity }=\text { NoisyOR }(\text { port accessibility, } \\
0.75, \text { geographical location }, 0.75,0.20)
\end{gathered}
$$

The above equation means that port accessibility and geographical locations are equally responsible to obtain desired connectivity and there are other hidden factors directly or indirectly influencing to achieve preferred port connectivity.

3.1.11. Port Environment (Criterion \#6). Two main subcriteria, emission at port and probability of natural disaster, 
TABLE 10: Modelling of variables related to emission at the port.

\begin{tabular}{lcc}
\hline Variable Name & Modelling Technique & Description \\
\hline $\mathrm{CO}_{2}$ Level & TNORM & $\begin{array}{c}\text { The level of } \mathrm{CO}_{2} \text { emission (million tonnes/year) follows a truncated normal distribution } \\
\text { (TNORM) with an average of } 15 \text { and variance of 2.5. The level of } \mathrm{CO}_{2} \text { emission (million } \\
\text { tonnes/year) never goes below } 12 \text { (lower bound) and 18.5 (upper bound), according to the } \\
\text { historical data for the inland waterway port. }\end{array}$ \\
\hline $\mathrm{NO}_{\mathrm{x}}$ Level & TNORM & $\begin{array}{c}\text { The level of } \mathrm{NO}_{\mathrm{x}} \text { (million tons/year) follows a truncated normal distribution with an average } \\
\text { of } 0.2, \text { the variance of } 0.005 \text { with lower bound and upper bound of .1 million tons/year and } \\
0.4 \text { million tons/year, respectively. }\end{array}$ \\
\hline
\end{tabular}

TABLE 11: Modelling of emission at port variable.

\begin{tabular}{lcc}
\hline Variable Name & Modelling Technique & Modelling Description \\
\hline Emission at Port & Comparative Expression & $\begin{array}{c}\text { An IF logic is used for modelling "emission at port" node. The threshold for } \mathrm{CO}_{2} \text { and } \\
\mathrm{NO}_{\mathrm{x}} \text { level are considered to be } 18 \text { and } 0.2 \text { respectively. The emission index will meet } \\
\left(\text { true) if the levels of } \mathrm{CO}_{2} \text { and } \mathrm{NO}_{\mathrm{x}} \text { at the port are less than } 18 \text { million tons/year and } 0.2\right. \\
\text { million tons/year respectively. }\end{array}$ \\
\hline
\end{tabular}

TABLE 12: NPT for port environment.

\begin{tabular}{lcccc}
\hline Emission & \multicolumn{2}{c}{ True } & \multicolumn{2}{c}{ True } \\
\hline Disruption & False & True & False & True \\
\hline False & 0.2 & 0.15 & 0.15 & 0.05 \\
\hline True & 0.8 & 0.85 & 0.85 & 0.95 \\
\hline
\end{tabular}

are found as the main determinants to the environmental criterion for port performance.

(i) Emission at port: shipping emission has a substantial impact on the overall environment of the port. Most shipping emissions in ports account for discharges of $\mathrm{CO}, \mathrm{SO}_{\mathrm{x}}$, and $\mathrm{NO}_{\mathrm{x}}$. The quantity of total emissions depends on the type and size of vessel berth at the port. At the same time, emission due to regular port equipment also accounts for deterioration of the air quality of the port. In order to reduce these emissions, strong policy along with public awareness is required.

(ii) Probability of natural disaster: the inland waterway port is often susceptible to different natural disasters such as hurricanes, cyclones, drought, or flood, combined with the prevailing port temperature and humidity.

3.1.12. Modelling of Port Environment. Figure 3 shows that port environment mainly conditioned upon two determinants: disruption of probability and emission at the port. The Boolean node is used to express the probability of disruption and emission at the port. For instance, disruption probability of $15 \%$ means that, according to the historical data, there is a $15 \%$ chance that the inland port might be impacted by adverse weather conditions. Tables 10 and 11 show the procedures of modelling for emission at the port and its contributed variables.

The NPT is the probability table that summarizes the occurrence probability between the causal relationship nodes. NPT can be developed manually or achieved by eliciting the distribution or related expression. For a node without its parent node, the NPT would be simply the probability distribution of that specific node. NPT for port environment is shown in Table 12.

3.1.13. Modelling of Port Performance Indicator. The ultimate target node "port performance index" is conditioned on its contributed criteria (i) port facility, (ii) port availability, (iii) port economics, (iv) port service, $(v)$ port connectivity, and (vi) port environment. The posterior probability of PPI is calculated as the weighted sum of its contributed criteria. Initially, it is assumed that the weight of each factor is equally distributed. The general equation associated with a weighted mean (WMEAN) is presented in (12), where (i) is the number of variables connected (six in this case) to the weighted average node of port performance index (see Figure 2) and $W_{i}$ is the weight associated with the $i$ th variable.

$$
\begin{aligned}
\text { WMEAN }=\sum W_{i} A_{i},= & 1,2 \ldots n, \\
& \forall \mathrm{i}=10<W_{i}<1, \sum_{i} W_{i}=1
\end{aligned}
$$

To compare the port performance index, based on abovementioned criteria, the probability the probability of PPI being true is $87.82 \%$, meaning that there is $87.82 \%$ likelihood (chance) that the specific port will meet the performance standard based on the cited criteria.

\section{Validation of the Model}

In order to validate the structure of the BN model, apart from traditional methods, sensitivity analysis (SA) is considered a powerful technique. It is a useful approach to examine the impact of the contributors on the target node within the same model, i.e., which node has more impact to its connected node. This is obtained by recalculating the outcomes of the targeted node under possible alternative assumptions. The object of the SA is to check that the outcomes generated from the propagation analysis are consistent with the expert's expectation. To obtain more insights and better understanding of the simulation model, we used AgenaRisk software 


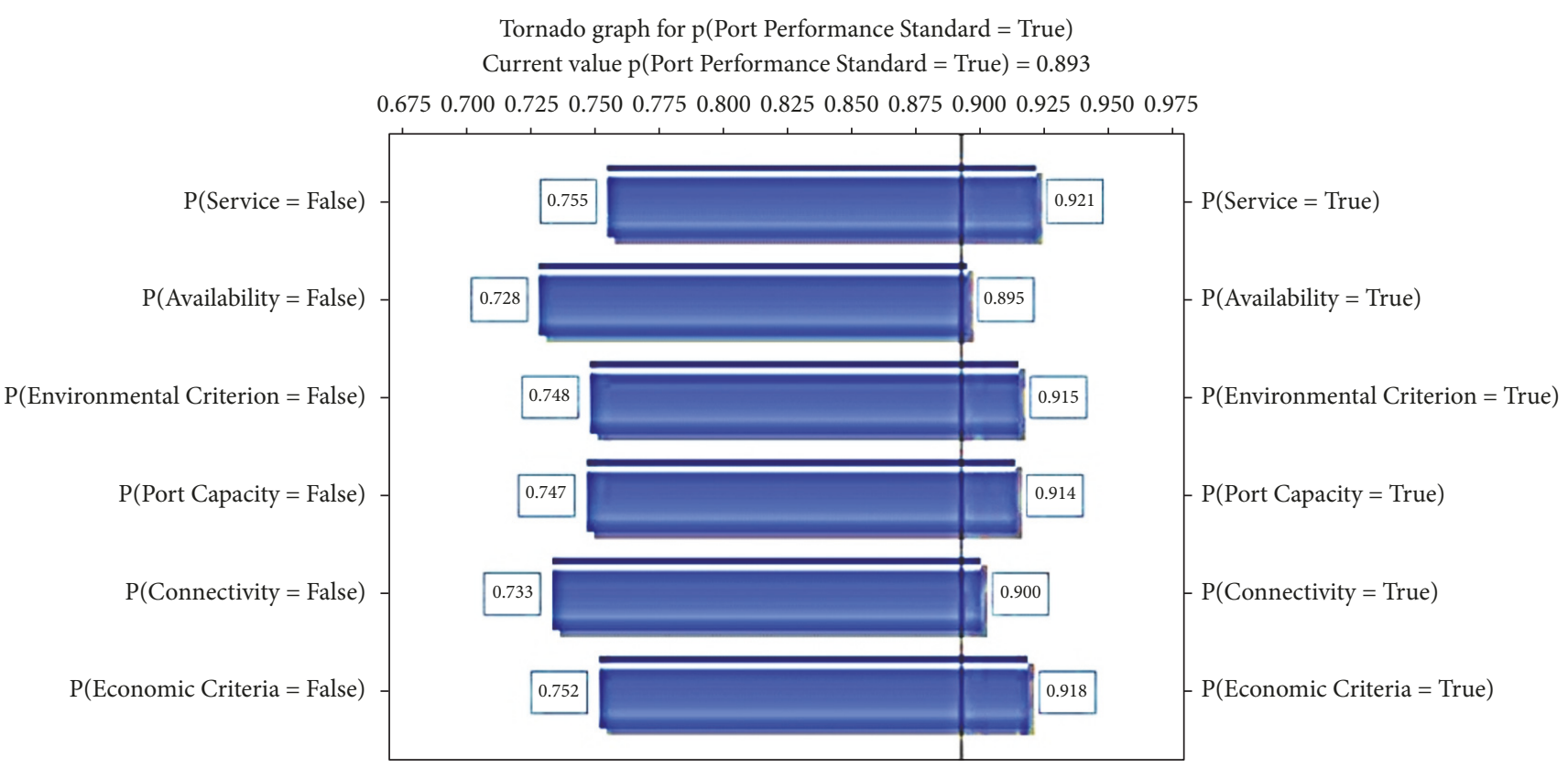

FIgURE 4: Sensitivity analysis of PPI.

to investigate the extent to which the six key performance contributors affect the port performance index. We performed SA on PPI as a target node with respect to its causal factors including (i) port facility, (ii) port availability, (iii) port economics, (iv) port service, ( $v$ ) port connectivity, and (vi) port environment as subsequently shown in Figure 3. Tornado charts, generated during the SA analysis, identified the lowest and highest values of a posterior probability for each possible state of the target node if specific observations are inputted into the model. To be more specific, the length of the bars corresponding to each sensitive node in the tornado graph illustrates a measure of the impact of that corresponding node on PPI. Figure 4 shows the impact of those variables when the PPI is "true." It is apparent from Figure 4 that the length of the bar chart for all the selected variables is almost same; however, port service has a slightly higher impact on PPI than other variables, whereas port economics has a lower impact on PPI among all the variables. To elaborate, from Figure 4 it is also apparent that the probability of PPI ("true") for the first port given the result of port service goes from 0.755 (when port service is "false") to 0.921 (when port service is "true"). In other words, the probability of PPI for first port is 0.921 when the port service is met. This range (0.755-0.921) is exactly the bar that is plotted in the tornado graph illustrated in Figure 4. This range varies from 0.752 to 0.918 for the port economics which implies port economics has the lowest impact on the PPI among all the variables. From Figure 4 it can also be interpreted that the probability of PPI for the port is more sensitive to the changes in the states of port service and least sensitive to changes in port economics. It can be concluded that although all the factors have almost same importance to the variability of PPI, port service ranked top in terms of contribution to the variability of PPI, and therefore the port authorities and top management should emphasize more on port service than others determinants.

\section{Propagation Analysis}

The feature of the BN to disseminate the effect of evidence through the network is defined as "propagation analysis". Special types of reasoning can be done through propagation analysis. During propagation analysis, different evidences (observations) can be entered anywhere in the underlying $\mathrm{BN}$ model to update the marginal probabilities of all unobserved variables. In this section, we have conducted forward propagation analysis to predict the probability distribution of PPI under the combination of the aforementioned six contributors. The related probability is represented in (13) (Zhou, 2018).

$$
\begin{aligned}
P( & \left.T=\text { State }_{t}\right)=\sum_{n=1}^{n}\left(P \left(P P I=\text { State }_{t} \mid A_{1}=a_{j}, A_{2}\right.\right. \\
& \left.=a_{j}, \ldots A_{n}=a_{j}\right) \times P\left(A_{1}=a_{j}, A_{2}=a_{j}, \ldots A_{n}\right. \\
& \left.=a_{j}\right)
\end{aligned}
$$

where $n$ refers the number of parent nodes and $a_{j}$ is the $i$ th state of the parent node. $\left(P\left(P P I=\right.\right.$ State $_{t} \mid A_{1}=a_{j}, A_{2}=$ $\left.a_{j}, \ldots A_{n}=a_{j}\right)$ is conditioned probability distribution when $T=$ State $_{t}$.

During the forward propagation analysis, we have designed two scenarios (1) pessimistic and (2) optimistic. Scenario 1 (pessimistic scenario) accounts for two assumptions: (i) the service hours of the port is set to 8 hours instead of truncated normal distribution with a mean of 16 hours and 
TABLE 13: Summary of propagation analyses.

\begin{tabular}{|c|c|c|c|c|c|}
\hline Scenario & $\begin{array}{l}\text { Description of the } \\
\text { Scenario }\end{array}$ & PPI & $\begin{array}{c}\text { Standard of } \\
\text { the Port }\end{array}$ & Significance of the propagation & Remarks \\
\hline Base Case & Underlying BN Model & $87.82 \%$ & Class B & - & - \\
\hline $\begin{array}{l}\text { Scenario } 1 \\
\text { (Pessimistic } \\
\text { Scenario) }\end{array}$ & $\begin{array}{c}\text { Service hr }=8 \mathrm{hr} \text {, Transit } \\
\text { time }=36 \mathrm{hr} \\
\text { (Other variables remain } \\
\text { unchanged) }\end{array}$ & $74.87 \%$ & Class C & $\begin{array}{l}\text { Shows how probability of PPI } \\
\text { changes with service level (service } \\
\text { availability and transit time) }\end{array}$ & $\begin{array}{l}\text { Port Service criterion has a } \\
\text { significant impact on the } \\
\text { probability of PPI. }\end{array}$ \\
\hline $\begin{array}{l}\text { Scenario } 2 \\
\text { (Optimistic } \\
\text { Scenario) }\end{array}$ & $\begin{array}{c}\text { Throughput }=30 \text { million } \\
\text { ton, Dredging } \\
\text { Maintenance }=100 \% \\
\text { True, } \\
\text { Port environment }=100 \\
\text { True } \% \text { (all } \\
\text { environmental criteria } \\
\text { are met) } \\
\end{array}$ & $91.28 \%$ & Class A & $\begin{array}{l}\text { Shows how probability of PPI varies } \\
\text { with port facility (throughput), port } \\
\text { availability (dredging maintenance) } \\
\text { and port environment. }\end{array}$ & $\begin{array}{l}\text { Port facility, port availability and } \\
\text { port environment have less } \\
\text { impact on the probability of PPI } \\
\text { compared to port service }\end{array}$ \\
\hline
\end{tabular}

(ii) the transit hours of the port are set to 36 hours in lieu of truncated normal distribution with an average of 30 hours. Scenario 1 measures the changes in the probability of PPI of the first port if the service hours reduced to a constant value of 8 hours and transit time increased to a constant value of 36 hours. From Figure 5, the probability of PPI of the first port significantly reduced from $87.82 \%$ to $74.87 \%$ which indicates the importance of service hours and transit time on PPI. Scenario 2 (optimistic scenario) simulates the impact of throughput, dredging maintenance, and port environment on PPI for the inland port. We set the throughput to 30 million/year, dredging maintenance and environmental as $100 \%$ instead of their prior distribution parameters which increases the PPI from $87.82 \%$ to $91.28 \%$ (see Figure 6). This type of propagation analysis gives the capability to decision makers to make any number of observations especially on variables with inherent uncertainty and measures.

A summary of propagation analyses is s given in Table 13. Scenario 1 and 2 are illustrated in Figures 5 and 6, respectively.

\section{Conclusion}

In this study, a novel dimensionless metric named port performance indicator (PPI) is introduced to assess the level of port performance based on six basic determinates named: port facility, port availability, port economics, port service, port connectivity, and port environment. In order to calculate the probability of PPI, we developed a Bayesian framework that captures the possible factors and subfactors pertaining to the level of port performance. The PPI indicates the level of performance that will be met by a specific port. It also provides a better understanding regarding the performance of a specific port under uncertainty. The PPI will aid port stakeholders in making better decisions in terms of the management of port supply chain and infrastructure. Such decisions include the number of port service hours, scaling port throughput, and others. In real-world practices, it is quite difficult to predict a port performance because of uncertainty and ambiguity (e.g., operational uncertainty, disruption uncertainty, etc.). In response, predicting the PPI through the Bayesian approach can help to substantially reduce this uncertainty and will ensure better visibility for decision-making. Belief propagation feature of the Bayesian approach allows practitioners to run different future scenarios where assumptions and alterations in conditions or states can be tested and verified. Belief propagation analysis also demonstrates the weightage of interdependency among the different variables of the underlying $\mathrm{BN}$ structure. The $\mathrm{BN}$ structure is also validated through sensitivity analysis. The general interpretation of the sensitivity analysis indicates that all six criteria are important to predict PPI; however, port service has a slightly higher impact and port economics has a lower impact among all factors in predicting the probability of PPI. The novelty of this work is summarized.

(i) The development of a model to assess port performance indicator (PPI).

(ii) The underlying determinates pertaining to port performance were identified and classified with respect to six main factors named: port facility, port availability, port service, port economics, port connectivity, and port environment.

(iii) The proposed model is then tested and validated through different types of analysis to draw better managerial insights to handle uncertainties. Results indicate that all the factors have almost same importance to the variability of PPI, port service ranked top in terms of contribution to the variability of PPI, and therefore the port management should stress more on service criterion than others factors.

(iv) Demonstrate the efficacy of BN as an effective tool in solving transportation and logistics management problems.

This study can be extended in several research directions. In our study, NPT has been defined based on subjective judgment (expert opinion) and frequentist approach (historical data). Other methods such as swing weights, Delphi technique, and the classical method can be used to improve the accuracy of NPT. Furthermore, a deep investigation is required to identify the other related factors that might indirectly impact the PPI. 


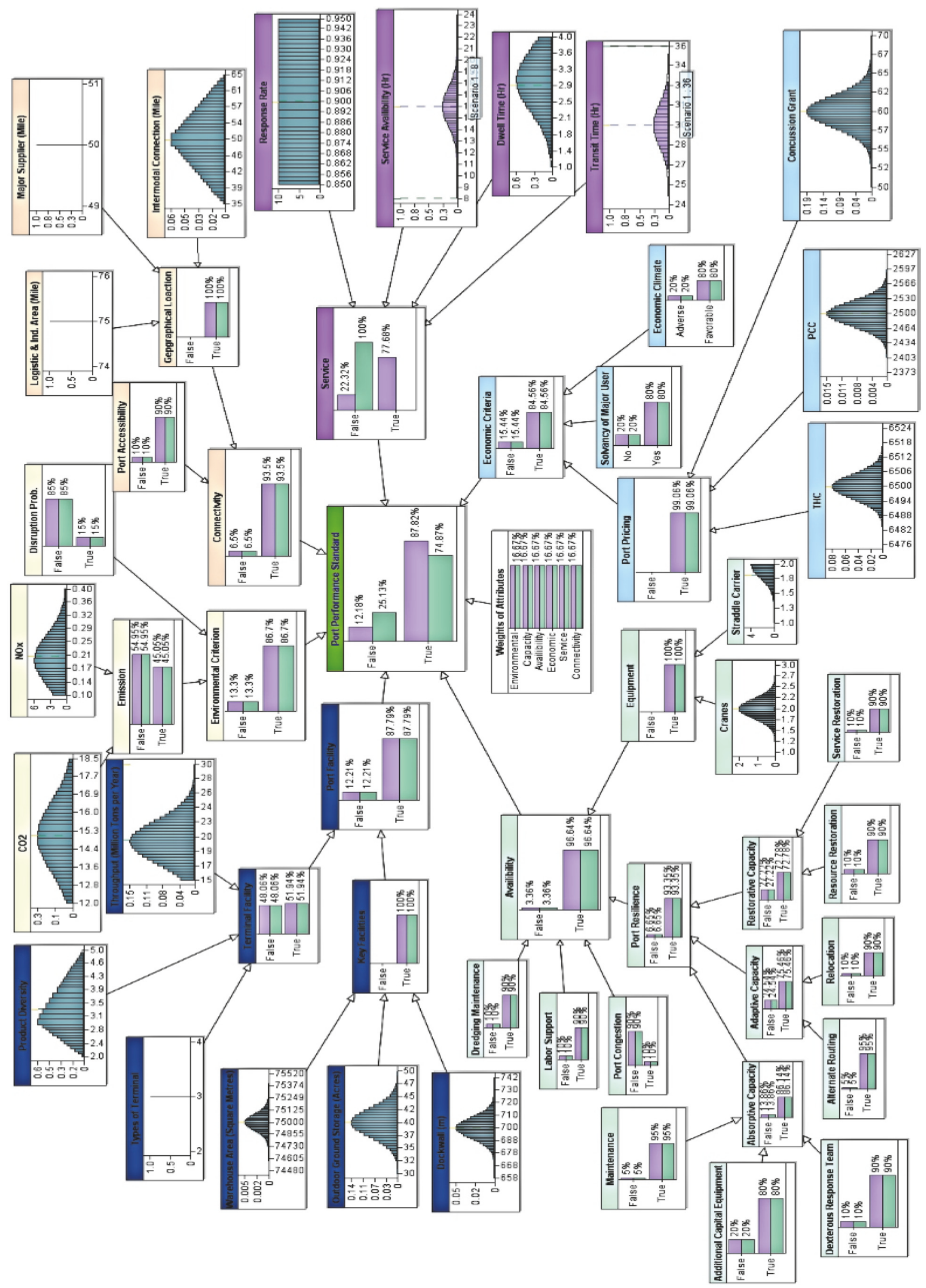

FIGURE 5: The developed BN model for scenario 1. 


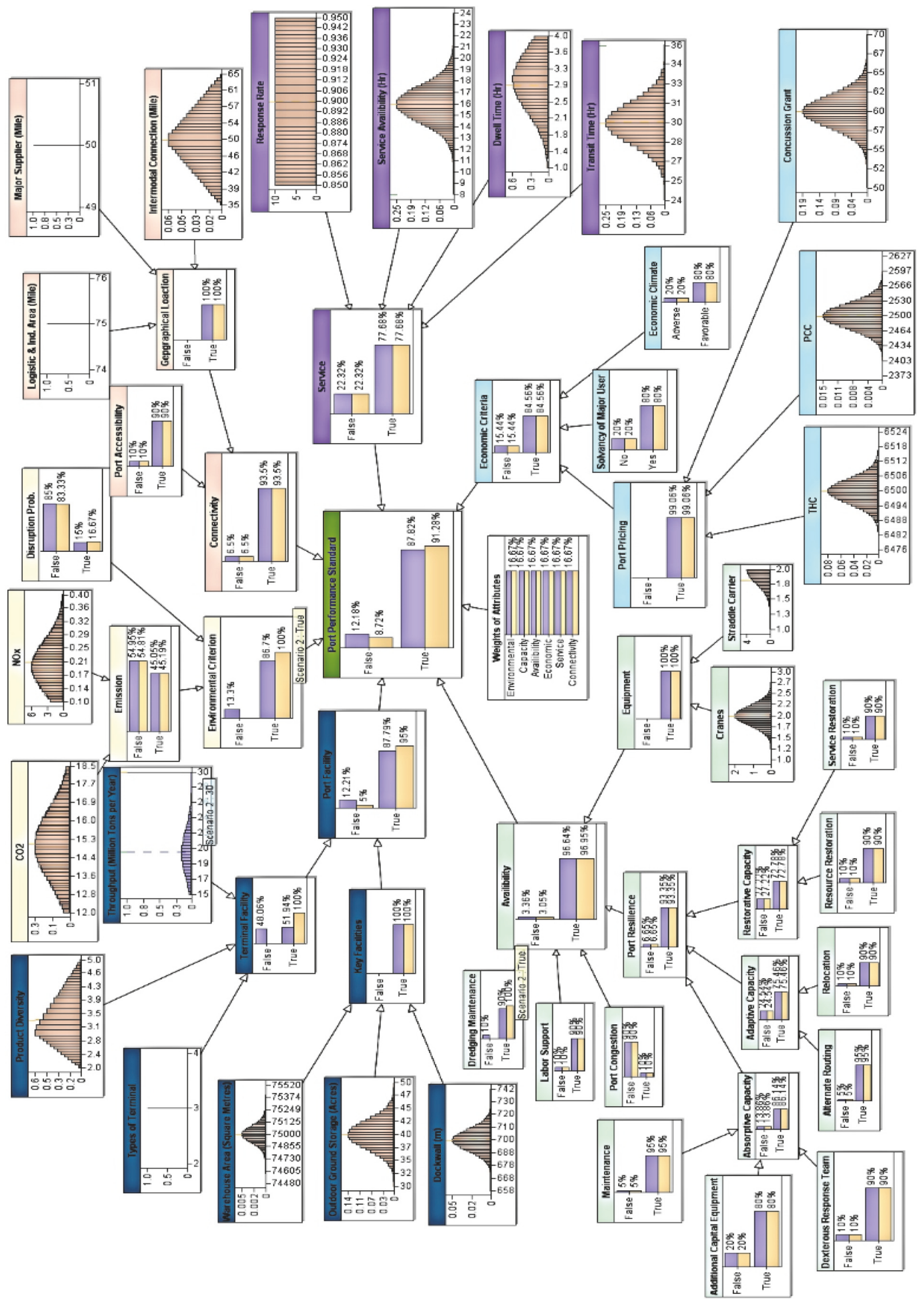

FIgURE 6: The developed BN model for scenario 2. 


\section{Data Availability}

The data used to support the findings of this study are available from the corresponding author upon request.

\section{Conflicts of Interest}

The authors declare that they have no conflicts of interest.

\section{References}

[1] M. Stopford, Maritime Economics, Routledge Press, 2013.

[2] Transportation Research Board, The Marine Transportation System and the Federal Role: Measuring Performance, Targeting Improvement, vol. 279, Transportation Research Board, 2004.

[3] C. R. Miller, "The evolving role of rural river ports as strategic economic development actors," Water Resources and Rural Development, vol. 9, pp. 28-38, 2017.

[4] National Research Council, Funding and Managing the US Inland Waterways System: What Policy Makers Need to Know, Transportation Research Board Publishers, 2015.

[5] X. H. Lim, P. Senter, J. Villars, and K. Watts-Fitzerland, "Is the port authority underperforming? An operational efficiency analysis of port authority's divisions," 2014, http://mpaenvironment.ei.columbia.edu/files/2014/06/Columbia_Port_Authority_ Final_Report_05132014.pdf.

[6] P. de Langen, M. Nidjam, and M. van der Horst, "Indicators to measure port performance," Journal of Maritime Research, vol. 4, no. 1, pp. 23-36, 2007.

[7] D. K. Shetty and G. S. Dwarakish, "Measuring port performance and productivity," ISH Journal of Hydraulic Engineering, pp. 1-7, 2018.

[8] N. U. I. Hossain, F. Nur, and R. M. Jaradat, "An analytical study of hazards and risks in the shipbuilding industry," in Proceedings of American Society for Engineering Management Annual Conference, pp. 18-21, Charlotte, NC, USA, 2016.

[9] N. U. I. Hossain and R. Jaradat, "A Synthesis of definitions for systems engineering," in Proceedings of the International Annual Conference of the American Society for Engineering Management, pp. 1-10, American Society for Engineering Management (ASEM), 2018.

[10] A. Alfaqiri, N. U. Hossain, R. Jaradat et al., "A systemic approach for disruption risk assessment in oil and gas supply chains," International Journal of Critical Infrastructures, vol. 15, no. 3, 2019.

[11] N. Kutin, T. T. Nguyen, and T. Vallée, "Relative efficiencies of ASEAN container ports based on data envelopment analysis," Asian Journal of Shipping and Logistics, vol. 33, no. 2, pp. 67-77, 2017.

[12] A. S. M. Alamoush, The impact of hinterland transport on port operational performance: a Jordanian case [Masters Dissertation], World Maritime University, Malmö, Sweden, 2016.

[13] G. Figueiredo De Oliveira and P. Cariou, "The impact of competition on container port (in)efficiency," Transportation Research Part A: Policy and Practice, vol. 78, pp. 124-133, 2015.

[14] K. Bichou and R. Gray, "A logistics and supply chain management approach to port performance measurement," Maritime Policy \& Management, vol. 31, no. 1, pp. 47-67, 2004.

[15] P. Coto-Millan, J. Banos-Pino, and A. Rodriguez-Alvarez, "Economic efficiency in Spanish ports: some empirical evidence," Maritime Policy Management, vol. 27, no. 2, pp. 169-174, 2000.
[16] T. Notteboom, C. Coeck, and J. Van Den Broeck, "Measuring and explaining the relative efficiency of container terminals by means of Bayesian stochastic frontier models," International Journal of Maritime Economics, vol. 2, no. 2, pp. 83-106, 2000.

[17] C. P. Barros, "Decomposing growth in Portuguese seaports: a frontier cost approach," Maritime Economics \& Logistics, vol. 7, no. 4, pp. 297-315, 2005.

[18] J. J. Díaz-Hernández, E. Martínez-Budría, and S. Jara-Diaz, "Parametric estimation of inefficiency in cargo handling in Spanish ports," Journal of Productivity Analysis, vol. 30, no. 3, pp. 223-232, 2008.

[19] P. M. Panayides, C. N. Maxoulis, T.-F. Wang, and K. Y. A. Ng, "A critical analysis of DEA applications to seaport economic efficiency measurement," Transport Reviews, vol. 29, no. 2, pp. 183-206, 2009.

[20] P. F. Wanke, "Physical infrastructure and shipment consolidation efficiency drivers in Brazilian ports: a two-stage networkDEA approach," Transport Policy, vol. 29, pp. 145-153, 2013.

[21] V. Chang and B. Tovar, "Drivers explaining the inefficiency of Peruvian and Chilean ports terminals," Transportation Research Part E: Logistics and Transportation Review, vol. 67, pp. 190-203, 2014.

[22] V. Chang and B. Tovar, "Heterogeneity unobserved and efficiency: A latent class model for west coast of south pacific port terminals," Journal of Transport Economics and Policy, vol. 51, no. 2, pp. 139-156, 2017.

[23] B. Tovar and A. Wall, "Can ports increase traffic while reducing inputs? technical efficiency of spanish port authorities using a directional distance function approach," Transportation Research Part A: Policy and Practice, vol. 71, pp. 128-140, 2015.

[24] K. Bichou and R. Gray, "A critical review of conventional terminology for classifying seaports," Transportation Research Part A: Policy and Practice, vol. 39, no. 1, pp. 75-92, 2005.

[25] S. Hosseini and K. Barker, "Modeling infrastructure resilience using Bayesian networks: A case study of inland waterway ports," Computers \& Industrial Engineering, vol. 93, pp. 252-266, 2016.

[26] S. Hosseini and K. Barker, "A Bayesian network model for resilience-based supplier selection," International Journal of Production Economics, vol. 180, pp. 68-87, 2016.

[27] J. P. Sierra, A. Genius, P. Lionello, M. Mestres, C. Mösso, and L. Marzo, "Modelling the impact of climate change on harbour operability: the Barcelona port case study," Ocean Engineering, vol. 141, pp. 64-78, 2017.

[28] C. Ugboma, O. Ugboma, and I. C. Ogwude, "An analytic hierarchy process (AHP) approach to port selection decisions - empirical evidence from Nigerian ports," Maritime Economics \& Logistics, vol. 8, no. 3, pp. 251-266, 2006.

[29] Y.-T. Chang, S.-Y. Lee, and J. L. Tongzon, "Port selection factors by shipping lines: Different perspectives between trunk liners and feeder service providers," Marine Policy, vol. 32, no. 6, pp. 877-885, 2008.

[30] D. A. Gohomene, Z. L. Yang, S. Bonsal, E. Maistralis, J. Wang, and K. X. Li, "The attractiveness of ports in West Africa: some lessons from shipping lines' port selection," Growth and Change, vol. 47, no. 3, pp. 416-426, 2016.

[31] F. Nur, M. Marufuzzaman, R. Burch, S. M. Puryear, and E. S. Wall, "Analyzing the competitiveness of inland waterway ports: An application of stochastic analytical hierarchy process," in Proceedings of the Industrial and Systems Engineering Conference, Orlando, Fl, USA, 2018. 
[32] D.-W. Song and K.-T. Yeo, "A competitive analysis of Chinese container ports using the analytic hierarchy process," Maritime Economics \& Logistics, vol. 6, no. 1, pp. 34-52, 2004.

[33] G.-T. Yeo, M. Roe, and J. Dinwoodie, "Measuring the competitiveness of container ports: Logisticians' perspectives," European Journal of Marketing, vol. 45, no. 3, pp. 455-470, 2011.

[34] N. Fenton and M. Neil, Risk Assessment and Decision Analysis with Bayesian Networks, CRC Press, 2012.

[35] N. U. I. Hossain, R. Jaradat, S. Hosseini, M. Marufuzzaman, and R. K. Buchanan, "A framework for modeling and assessing system resilience using a Bayesian network: A case study of an interdependent electrical infrastructure system," International Journal of Critical Infrastructure Protection, vol. 25, pp. 62-83, 2019.

[36] M. Zhang, L. Wang, S. Jajodia, A. Singhal, and M. Albanese, "Network diversity: a security metric for evaluating the resilience of networks against zero-day attacks," IEEE Transactions on Information Forensics and Security, vol. 11, no. 5, pp. 10711086, 2016.

[37] B. Song, C. Lee, and Y. Park, "Assessing the risks of service failures based on ripple effects: A Bayesian network approach," International Journal of Production Economics, vol. 141, no. 2, pp. 493-504, 2013.

[38] M. Hänninen, "Bayesian networks for maritime traffic accident prevention: benefits and challenges," Accident Analysis \& Prevention, vol. 73, pp. 305-312, 2014.

[39] S. Hosseini, A. Al Khaled, and M. D. Sarder, "A general framework for assessing system resilience using Bayesian networks: A case study of sulfuric acid manufacturer," Journal of Manufacturing Systems, vol. 41, pp. 211-227, 2016.

[40] A. Grêt-Regamey, S. H. Brunner, J. Altwegg, and P. Bebi, "Facing uncertainty in ecosystem services-based resource management," Journal of Environmental Management, vol. 127, pp. S145-S154, 2013.

[41] E. Pérez-Miñana, P. J. Krause, and J. Thornton, "Bayesian Networks for the management of greenhouse gas emissions in the British agricultural sector," Environmental Modeling and Software, vol. 35, pp. 132-148, 2012.

[42] L. M. Saini, "Peak load forecasting using Bayesian regularization, Resilient and adaptive backpropagation learning based artificial neural networks," Electric Power Systems Research, vol. 78, no. 7, pp. 1302-1310, 2008.

[43] C. Arizmendi, D. A. Sierra, A. Vellido, and E. Romero, "Automated classification of brain tumours from short echo time in vivo MRS data using Gaussian Decomposition and Bayesian Neural Networks," Expert Systems with Applications, vol. 41, no. 11, pp. 5296-5307, 2014.

[44] S. Hosseini and M. D. Sarder, "Development of a Bayesian network model for optimal site selection of electric vehicle charging station," International Journal of Electrical Power \& Energy Systems, vol. 105, pp. 110-122, 2019.

[45] S. Hosseini, D. Ivanov, and A. Dolgui, "Review of quantitative methods for supply chain resilience analysis," Transportation Research Part E: Logistics and Transportation Review, vol. 125, Part E, pp. 285-307, 2019.

[46] S. Hosseini, N. Morshedlou, D. Ivanov, M. D. Sarder, K. Barker, and A. Al Khaled, "Resilient supplier selection and optimal order allocation under disruption risks," International Journal of Production Economics, vol. 213, pp. 124-137, 2019.
[47] M. Perkusich, G. Soares, H. Almeida, and A. Perkusich, "A procedure to detect problems of processes in software development projects using Bayesian networks," Expert Systems with Applications, vol. 42, no. 1, pp. 437-450, 2015.

[48] Y. Zhou, C. Li, C. Zhou, and H. Luo, "Using Bayesian network for safety risk analysis of diaphragm wall deflection based on field data," Reliability Engineering \& System Safety, vol. 180, pp. 152-167, 2018.

[49] U.S. Department of Transportation, "Port performance freight statistics program,” 2017, https://www.bts.gov/sites/bts.dot.gov/ files/docs/browse-statistical-products-and-data/port-performance/216906/port-performance-2017-revised-2-12-18.pdf.

[50] J. P. Rodrigue, C. Comtois, and B. Slack, The Geography of Transport Systems, Routledge, 2009.

[51] E. D. Vugrin, D. E. Warren, and M. A. Ehlen, "A resilience assessment framework for infrastructure and economic systems: quantitative and qualitative resilience analysis of petrochemical supply chains to a hurricane," Process Safety Progress, vol. 30, no. 3, pp. 280-290, 2011.

[52] S. Hosseini, K. Barker, and J. E. Ramirez-Marquez, "A review of definitions and measures of system resilience," Reliability Engineering \& System Safety, vol. 145, pp. 47-61, 2016.

[53] B. Cai, M. Xie, Y. Liu, Y. Liu, and Q. Feng, "Availability-based engineering resilience metric and its corresponding evaluation methodology," Reliability Engineering \& System Safety, vol. 172, pp. 216-224, 2018.

[54] Q. Feng and Y. Ren, "Resilience design method based on meta-structure: a case study of offshore wind farm," Reliability Engineering System Safety, 2019.

[55] Pacific merchant shipping association, "Container dwell time - Metrics for port efficiency \& velocity," 2016, http://www .pmsaship.com/pdfs/PMSA\%20Press\%20Release\%20Container\% 20Dwell\%20Time\%2011-17-16.pdf.

[56] J.-P. Rodrigue and T. Notteboom, "The terminalization of supply chains: Reassessing the role of terminals in port/hinterland logistical relationships," Maritime Policy \& Management, vol. 36, no. 2, pp. 165-183, 2009. 


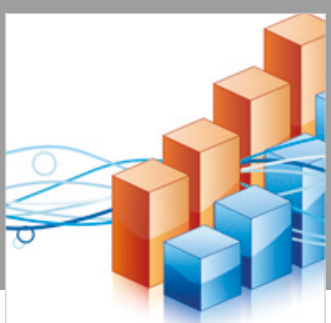

Advances in

Operations Research

\section{-n-m}
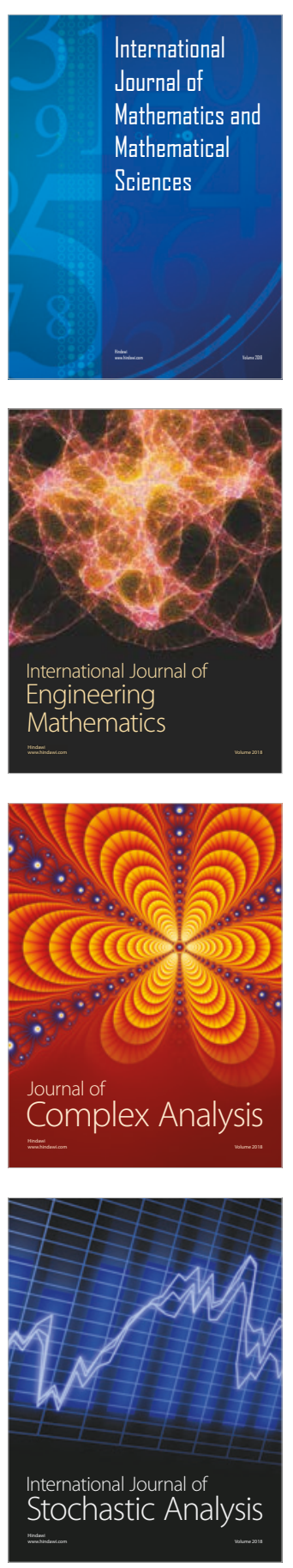
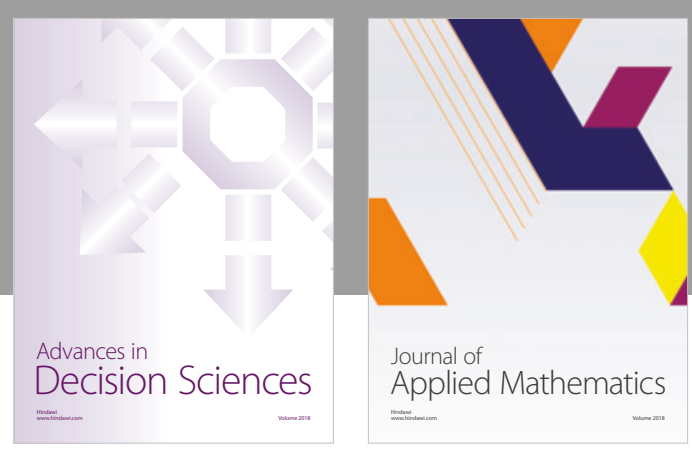

Journal of

Applied Mathematics
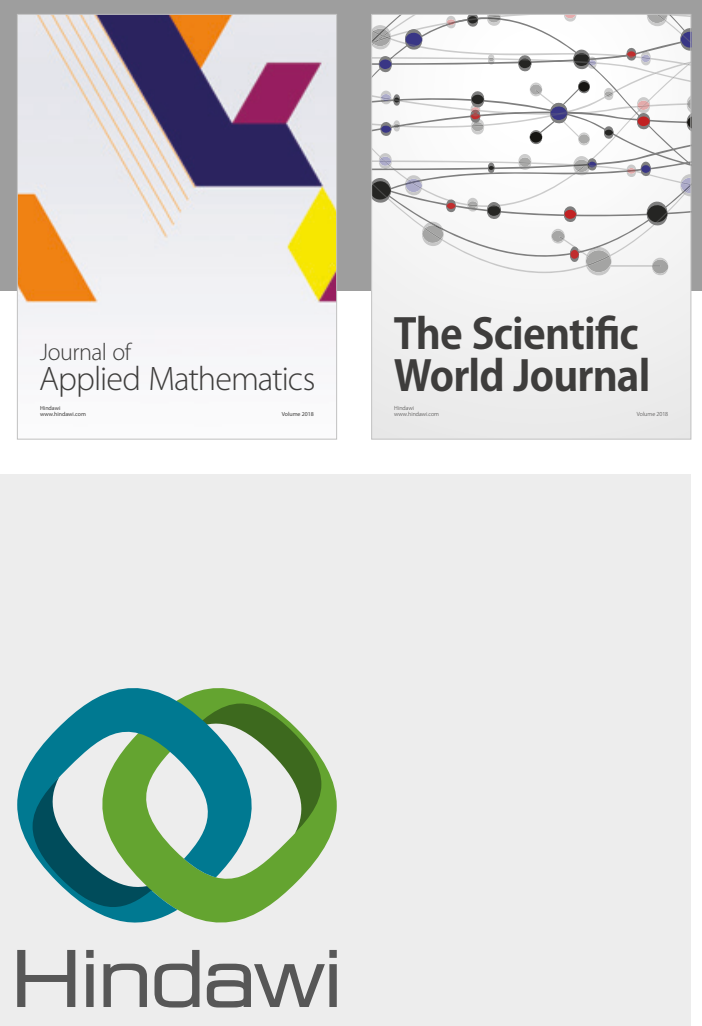

Submit your manuscripts at

www.hindawi.com

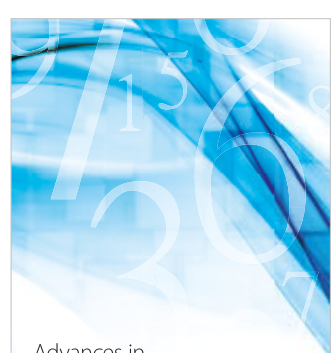

Advances in
Numerical Analysis
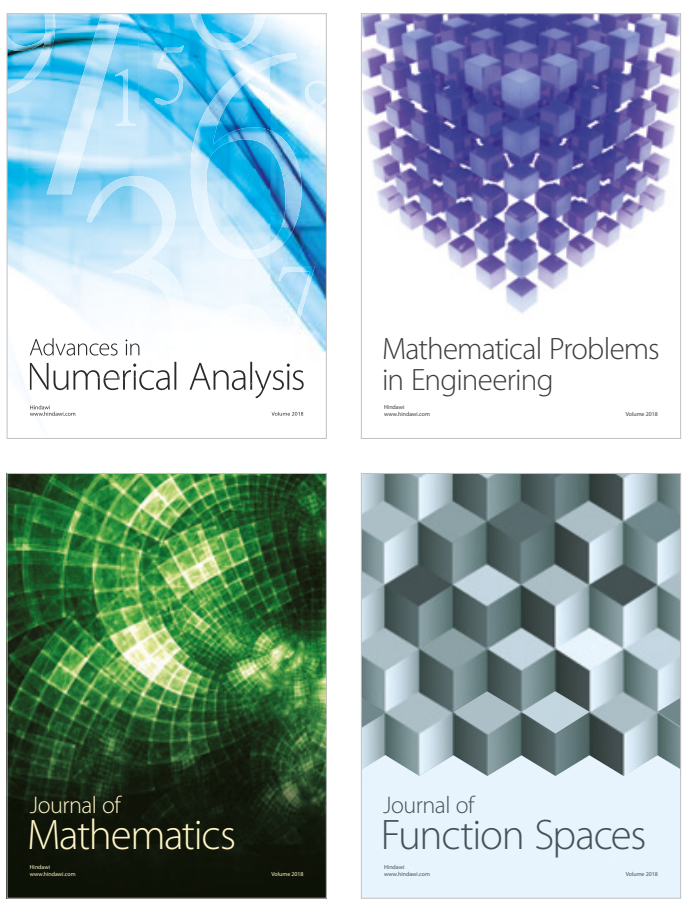

Mathematical Problems in Engineering

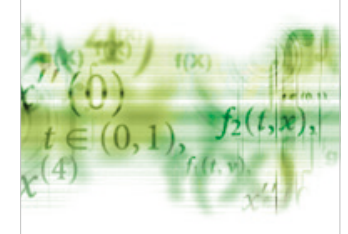

International Journal of

Differential Equations

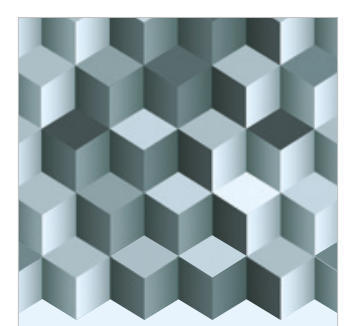

Journal of

Function Spaces
The Scientific

World Journal

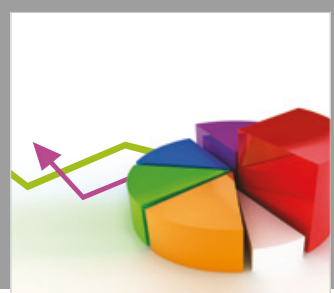

Journal of

Probability and Statistics
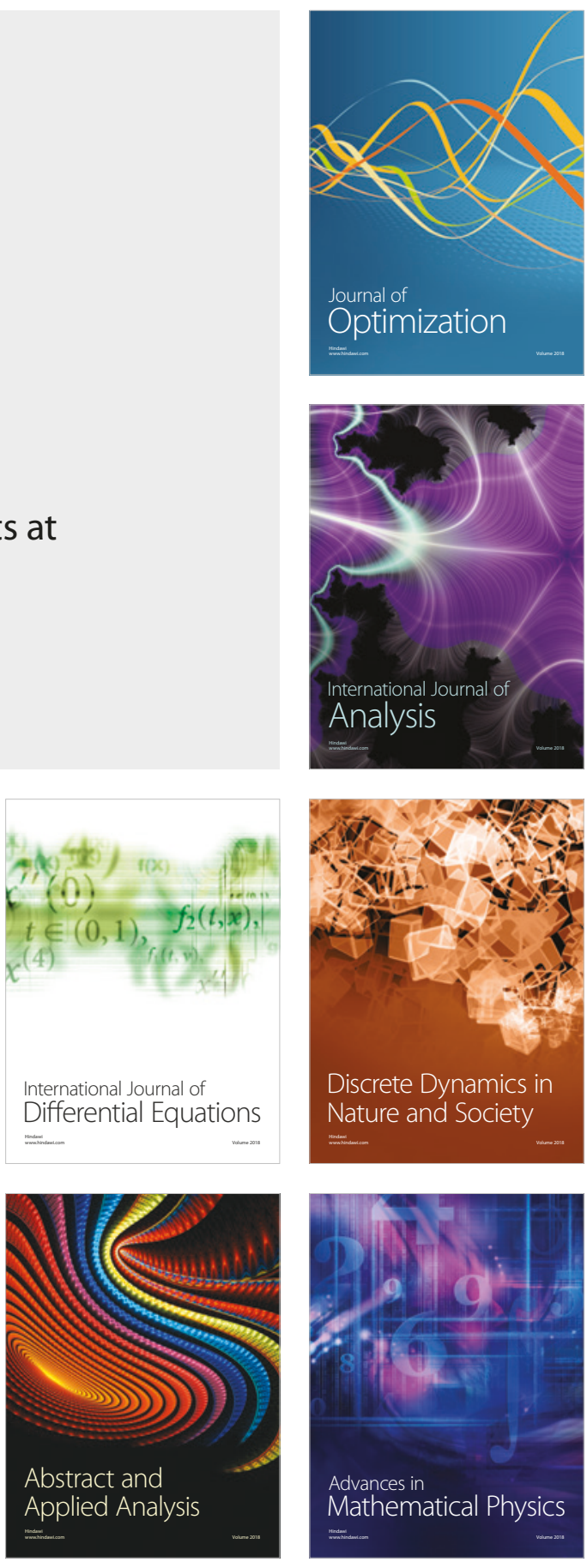